\title{
RELIGIOUS RESPONSES TO GLOBALISATION
}

\author{
Hatib A. Kadir \& Maufur ${ }^{1}$ \\ Center of Religious \& Cross-Cultural Studies (CRCS) \& Indonesian \\ Consortium for Religious Studies (ICRS), Yogyakarta, Indonesia
}

\section{Abstract}

Sociological discussion of globalisation is preoccupied with the political, economic, and military dimension of it, with little attention to its religious aspect. This paper attempts to trace the impacts of globalisation on religion and religious responses, the argument of which derives mainly from the so-called "Bridge-Building Program" organised by CRCS \& ICRS-UGM in 2008. It argues that though they share a common concern, people of different faiths are at risk of deepening the problems rather than offering solutions in view of their different responses for which we categorise them into different but overlapping categories-ideological, ambivalent, integrative, exclusive, and imitative. It then leads to a more fundamental question of whether interfaith cooperation is possible given those different and sometime opposing responses.

Dalam kajian sosiologi, diskusi mengenai globalisasi kerap kali sematamata ditinjau dari sisi politik, enonomi dan militer, sementara dimensi agama sering kali dikesampingkan. Artikel ini membahas dampak globalisasi terhadap agama dan respon komunitas agama terhadap globalisasi. Data yang muncul dalam artikel ini diambil dari sebuah workshop berjudul"BridgeBuilding Program." Melalui artikel ini, saya berpendapat bahwa, meski

1 This article was inspired by consecutive workshops entitled "Bridge-Building Program" conducted by CRCS \& ICRS, in cooperation with Hivos \& The Oslo Coalition, March-July, 2008. This program includes a number of leaders from different religious groups. 
komunitas agama-agama memiliki keprihatinan yang sama terhadap dampak globalisasi, namun respon mereka cenderung mempertajam persoalan yang diakibatkan globalisasi, ketimbang memberikan solusi. Respon tersebut dalam dikategorikan -meski tidak kaku-dalam: respon ideologis, ambivalen, integratif, ekslusif dan imitatif. Selanjutnya, artikel juga mengulas pada pertanyaan mendasar mengenai apakah kerjasama antar agama mungkin dilakukan menyimak ragam respon yang saling bertentangan tersebut.]

Keywords: religion, globalisation, responses

\section{A. Introduction}

The term globalisation "refers to the expansion and intensification of social relations and consciousness across world-time and worldspace." ${ }^{2}$ It enables people to go beyond their traditional political, economic, and geographical boundaries and at the same time exposes them to new social orders that cut across their localities. People of all regions are by no exception becoming global consumers due to the global financial market. Technologically sophisticated innovation in information and transportation has intensified and accelerated social exchanges, and therefore creating more interdependence between the local and the global. In addition to its objective material impacts, globalisation affects also subjective consciousness by giving birth new individual and collective identities. It generated the so-called 'global village' where people of different identities and geographies easily meet and share knowledge. To take an example, the program from which this paper is inspired easily illustrates the case. Muslim participants were sitting next to their Christian, Buddhist, or Hindus fellows, talking and sharing their ideas in an air-conditioned conference room equipped with laptops and projectors. The internet and cellular made it possible for the committee to contact all participants who are miles away. The recorded materials made it accessible to "strange people" overseas.

Mass media, such as television and internet, has become the most powerful medium for globalisation to extend its cultural invasion through which it inclines the desires and life styles of its consumers toward a

${ }^{2}$ Manfred B. Steger, Globalization: A Very Short Introduction, (Oxford: Oxford University Press, 2009), p. 15. 
particular kind of value, while at the same time it challenges traditional beliefs and norms. The cultural hegemony of popular culture among the youth, for instance, has attracted wide and serious attentions from parents, authorities, or religious leaders. In term of world-economics, globalisation seems to have created "the winners" and "the losers." On one hand, it helped countries such as China, India, Bangladesh and Vietnam in reducing largely their poverty levels. On the other hand, the liberalisation of transactions, with transnational cooperation (TNCs) as the main actors in the global economic world, was behind some financial crisis in South East Asia in 1997, or currently in the United States, or economically failed states such as Afghanistan or the Democratic Republic of Congo. Another salient impact of globalisation is environmental crisis, which killed and endangered lives of people both in a local or global scale.

The question is then how should religion respond to the above impacts of globalisation? There is no doubt that all religions share a common goal to improve the individual and social conditions of human beings. However, this divine and invaluable goals should now deal with a greater challenge of the pervasive impacts of globalisation. There is no doubt that globalisation provides rich opportunities to attain such a goal, but at the same time, it may increase religious violence and intolerance, particularly when it means to exclude and neglect differences. This paper aims to answer such question by building its argument upon the discussion among the participants during the "Bridge-Building Dialogue" program

\section{B. Globalisation: Definition}

Definition of the term "globalisation" is still debatable among scholars of various disciplines. Many scholars put forward their definitions with different emphasis on the multifaceted aspects of the term: economic, political, cultural or ideological. Steger's illustration of the ancient Buddhist parable of the blind scholars and their encounter with the elephant might be helpful to highlight the debate. He said:

Like the blind men in the parable, each globalisation researcher is partly right by correctly identifying one important dimension of the phenomenon in question. However, their collective mistake lies in their dogmatic attempts to reduce such a complex phenomenon as globalisation 
to a single domain that corresponds to their own expertise. ${ }^{3}$

Sociologists may be of the most significant influence in debate on definitions and theories of globalisation. Marshall McLuhan proposed the term 'global village' in his definition of the term. In his opinion, globalisation refers to the situation where the speed of communication has governed a complex range of social interconnections beyond the boundaries of national, cultural and political spaces. In this globalised world, people of different locations, through information media, can experience events simultaneously. ${ }^{4}$ Anthony Giddens defines the term as 'the intensification of worldwide social relations which link distant localities in such a way that local happenings are shaped by events occurring many miles away and vice vers $a .{ }^{5}$ Robertson holds that globalisation is a concept that "refers both to the compression of the world and the intensification of consciousness of the world as a whole."

In its modern sense, globalisation is a set of dimensions rather than a single process. William A. Stahl, for example, identifies its five dimensions that include revolution in communication and transportation technology, politics and military, economics, environment, religion and cultures. ${ }^{6}$ The inventions of mass air travel, cable and satellite TV, cellular telephones, computers, and the Internet in the 1980s and 1990s has made technologies in communication and transportation become truly revolutionary. The politic and military dimension of globalisation began with the fall of the Soviet Union and the end of the Cold War, leading to what people believe as the U.S. hegemony. The globalisation of economics began with the rise of transnational corporations and infrastructure such as the International Monetary Fund and the World Bank established by the Bretton Woods Agreement in 1944. The environmental dimension of globalisation reflects on the fact that population growth and rapid development of technologies and industries has raised some acute environmental crisis. The last dimension of globalisation is religion and culture which Stahl said that though mostly felt and experienced by most

${ }^{3}$ Ibid., p.12.

${ }^{4}$ Larry Ray, Globalization: Everyday Life (New York: Routledge, 2007), p.1.

${ }^{5}$ Anthony Giddens, the Consequences of Modernity (Stanford University Press: Stanford, CT, 1990), p. 64.

${ }^{6}$ William A. Stahl, "Religious Opposition to Globalization," in Lori Beaman and Peter Beyer (eds.) Religion, Globalization and Culture (Leiden: Brill, 2007), pp. 336-9. 
people, analysts commonly neglected this last dimension. ${ }^{7}$ Like Stahl, Bryan S. Turner also acknowledged lack of attention in sociological theories toward religion as an inherent part of globalisation, focusing more on the economic, financial and military aspects of it. ${ }^{8}$ Accordingly, sociologists tend to understand 'religious fundamentalism' as reassertion of traditionalism vis-à-vis modernisation that is pivotal characteristics of the global world.

The case is not much different with respect of how the participants of the workshop understand globalisation. They understand it as a multifaceted event in which economic, political and cultural dimensions are involved. The participants are almost unanimous in seeing that globalisation has both positive and negative impacts on people's lives in general and on religious communities more specifically. Although they see it as an unavoidable feature of our contemporary life, their responses are various. It is understandable because the participants have different emphasis on the phenomena of globalisation, which include different interpretation of the main actors, of how religion can play its role, and different concepts of an ideal society according to their religion traditions.

How the participants understand religions can be best categorised in two different but overlapping approaches. The first views globalisation as a process of integration and interaction in which globalisation means integration of time and space which results in the increasingly reduced importance of the 'imaginary boundaries' of state territories, leading to the so-called 'global village.' Economic, socio-politic and cultural processes are among the main factors underlying this process of time and space integration. As time and space are reduced and integrated, national, religious and cultural exchange among people are intensified and accelerated as well, making them interdependent to each other. The second approach regards globalisation with emphasis on certain ideologies like capitalism ("McDonaldization" or "Americanisation"). The group who hold this approach argued that globalisation is not, and it is not all about, a mere process of turning the world into a global village through technological discoveries. Rather, it is imperialism of "Capitalism of the West" with its all faces such as colonialisation in the $19^{\text {th }}$ and $20^{\text {nd }}$

\footnotetext{
${ }^{7}$ Ray, Globalization, pp. 345-48.

${ }^{8}$ Ibid., p. 154
} 
centuries and its new form of modernisation and development after the end of the Second World War. ${ }^{9}$ In short, whatever the definition of globalisation is, it is closely related to certain values we introduced into our definition of the term, which in turn will determine our responses to its effects. That globalisation has both negative and positive affects is not questionable. The question is how we respond to them, particularly to the negative ones.

\section{Religion and Globalisation: Some Impacts}

It is commonly agreed that all great religions emerged in three centers of civilisation in the ancient world, i.e. China, India and the Middle East. All these religions spread over the continents and meet each other in other areas. As a result, we may see different sacred sites in one city where a mosque is next to a church, a temple, or a synagogue. The travel of religions and its embrace by more people led to what Lyotard called it as "loss of centre" in which we see a worldwide diffusion of religions and diaspora among their adherents and their sacred centers out of its first homeland. ${ }^{10}$ Similarly, Paul F. Knitter, drawing on David Loy, ${ }^{11}$ sees the phenomena of free market fundamentalism as the new world religion in which a religion, like a free market, is becoming new, universal, absolute, and exclusive all over the world.

In the modern period, world religious systems have a huge opportunity to transform themselves at a global scale because of an increasingly developed system of communication and transportation. Abrahamic religions (i.e. Judaism, Catholicism, and Islam) work on a largely globalised linkage and articulate themselves globally through trading and educational systems and networks. For example, relationship

${ }^{9}$ Nopriadi, "A Better World is a Must," unpublished paper presented at the workshop "Globalization, Media, and Education of the Youth, CRCS \& ICRS, March 8-9, 2008, pp. 3-4.

${ }^{10}$ John L. Esposito, Fasching Darrel, Lewis Todd, Religion and Globalization: World Religions in Historical Perspective (Oxford: Oxford University Press, 2008), p. 5

${ }^{11}$ David R. Loy, 'The Religion of the Market' in Journal of the American Academy of Religion, vol. 65, no. 2, Summer 1997, pp. 275-290; see also Paul Knitter, 'Globalization and the Religions: Friends or Foes?' unpublished paper presented on May 24, 2006 at a Research Seminar on Globalization and Religion: Friends or Foes?, Centre for Religious and Cross-Cultural Studies, Gadjah Mada University, Yogyakarta, Indonesia. 
between Islam in Malay-Indonesia and the Middle East has been established since the seventeenth century. Indonesian Muslims are inseparable from those in the Middle East, and this network plays a crucial role in transforming the impulses of Islamic reformism in Indonesian Archipelago. ${ }^{12}$

Globalism does not only affect the spread of religions, but also the diverse responses of the indigenous people toward those global Abrahamic religions. In every civilisation, confrontation, tension, and readjustment have always accompanied religious encounters. In Southeast Asia, encounters between Buddhism, Hinduism, Islam and Christianity took place in every state, such as Malaysia, Indonesia, Thailand and the Philippines. Many Arab traders who are mostly from Hadramaut, Buddhist monks who are mostly from Ceylon, and Chinese Con $\mathrm{Fu}$ Cian, come to the Archipelago for many centuries and represent a major source of "global" religions in Indonesia. Many of them serve as religious teachers as well as traders.

It seemed that religion through globalisation has moved to fill the economic gap between developed and developing countries. Many global religious movements like those in Islam, Western Christianity, Judaism, Buddhism and Hinduism were established across the boundaries of continents and nation-states. American Judaism that supports the Israeli State or the Middle Eastern states that stand for Malay Muslims of the Southern Thailand and the Southern Philippine might be good examples. Some scholars on religion, like George Weigel, Gilles Kepel and Peter L Berger ${ }^{13}$ said that global religions have raised a sense of "the unsecularization of the world" or "the revival of global religion" in which a particular religion transcends its national boundaries and economical gaps. Globalism has indeed generated a stronger feeling of religiosity than nation-states. For example, a person may be a half-French, a half-Arab,

${ }^{12}$ See further Azyumardi Azra, the Origins of Islamic Reformism in Southeast Asia: Networks of Malay-Indonesian and Middle Eastern "Ulama" in the Seventeenth and Eighteenth Centuries (University of Hawaii, 2004).

${ }^{13}$ See further these arguments in Gilles Kepel, the Revenge of God: The Resurgence of Islam, Christianity and Judaism in the Modern World (Polity Press Publisher, 1993); Peter L Berger, "Desecularization of the World, a Global Perspective" in Peter L Berger (ed.), the Secularization of the World, Resurgent World and World Politics (Ethic and Public Policy Centre, 1999). 
while simultaneously belonging to dual citizenships. On the contrary, it is almost impossible to be a half-Catholic and a half-Muslim.

Because of globalisation, the world is becoming smaller, inevitably leading to increasingly intensified interactions among peoples of different religions and cultures. This interaction, to some extent, enhances the civilisation-consciousness of the people, which in turn revitalises their differences and animosities that are deeply rooted in their thoughts and histories. Huntington ${ }^{14}$ describes that the raise of cultural identity has worsened the global paradox, which in turn leads to a clash of world civilisation. The numbers of civilisations, which consist of states, ethnicity, geographical proximity, linguistic similarity, social groups and predominantly religions, seemed to split exclusively into major civilisations. Western civilisation, which is centered in the Northern America, West Europe, and the former of Soviet Union states, are in fight with the Eastern Civilisation represented by the Buddhist culture in Thailand, Korea, Singapore, and the Hindus culture in India, and Japanese civilisations. This clash of civilisation becomes more complicated when the Muslim worlds represented by the Greater Middle East states such as Saudi Arabia, Iran, Iraq, and the North African states such as Egypt as well as the Muslim states in South Asia and Southeast Asia, including Indonesia, are also involved.

The theory of clash civilisation suggests that the fundamental cause of conflict nowadays is neither ideological nor economic, rather the great polarisation among the cultural humankind and its religions. Since the post-Cold War, the latter is embodied in the struggle among different cultural and religious identities, i.e. the Western civilisation visà-vis Islamic civilisation and the "rest" of civilisation. Reactions toward globalisation has strengthened those identities, the result of which is that people are defined mainly by their common objective elements, such as language, history, religion, customs, institutions, and their subjective selfidentifications. The fact that in the post-Cold War, the conflict between classes and ideologies of communism, socialism and nationalism is not debatable, during which one is not asked a question, "what side you are on?" rather "what are you?" (That is, "what is your religion?" or "what is

${ }^{14}$ See further Samuel Huntington, the Clash of Civilizations and the Remaking of World Order (New York: Simon and Schuster, 1996). 
your ethnicity," and so on). This phenomenon shows us that nation-states are not the only principal actors in the global affairs, but it also includes a sense of belongingness to ethnic and religious identities.

The global paradox of the clash of civilisation is not only true, but it also serves as a basic problem. The reason is that people is differentiated from each other by their historical experiences, languages, traditions, and, most importantly their religions. In addition, among those civilisations there are different views on relations between God and man, the holy texts and religious values, the individual and the group, the parents and the children, the husband and the wife, as well as those of the relative importance of rights and responsibilities. These differences are far more fundamental than those in political ideologies and regimes. For instance, some Indonesian people suggest that globalisation and religion are incompatible to each other. For this group, globalisation is rooted in modernity and neo-liberalism that follow from the greedy-Western philosophy, immorality, individualism and capitalist domination.

In addition to clash and confrontation, religious encounters are also accompanied with mystical interactions among different religions, from which a newly common culture and cosmology is born. The interaction between Hinduism and Christianity in the nineteenth century of Java resulted, for example, in the Javanese images of Jesus Christ in the Catholic Church or candi (temple) of Ganjuran. ${ }^{15}$ Indonesian religions appeared to be very different from those in other places. Islam in Indonesia is the most striking example. Islam in Indonesia is different from one in Arabian Peninsula because of strong influence from Indian religions (i.e. Hinduism and Buddhism) in the Archipelago, not to mention indigenous religions that are full of venerations, spirits and cults. Muslims of regionally and ethnically different origins first brought Islam to Indonesia, particularly from the entire coastline of South Arabia to Southern India and China. ${ }^{16}$ As a result, Islam in Indonesia was gradually incorporated into local practices. The encounters between global and local religions in Indonesia resulted also in the clash between adat (custom) visà-vis agama (religion), in which the former refers to locality in response to

${ }^{15}$ Merle Ricklefs, Polarizing Javanese Society, Islamic and Other Visions (c 1830-1930) (Honolulu: University of Hawaii Press, 2007), pp. 122-3.

${ }^{16}$ Azyumardi Azra, the Origins of Islamic Reformism. 
the global Islam. In modern Indonesia, some Muslims perceive that adat is in conflict with the notion of shari' $a$. As Muslims rapidly and increasingly diffuse from Arabia in the 1930s up to the current decentralisation era, local customs has repeatedly come under threats and attacks by the socalled reformists and "scripturalists."

In Indonesia, Islam becomes one of the most controversial religions over a decade because of the rapid growth of fundamentalist groups. Roughly, Islamic fundamentalism advocates totalism and rejects privatisation of religion. Islam is the religion of the majority in Indonesia, reaching over $90 \%$ of adherents out of the total number of Indonesian citizen. Because the concept of umma (Muslim communities) is transnational, the umma believe that they are unified regardless of the boundaries of nation-states. The rapid migration of Muslims lead to the vast number of Muslims in non-Arab worlds, like India, Pakistan, Bangladesh, Indonesia, and even in the West Europe. This vast diffusion of Muslims over the world represents the impact of the globalisation on religion. However, the problems emerge as some Muslims interpret that being a Muslim is not a matter of personal faith, rather it is also political, legalistic, and economic, due to which Islamic empires and states began to come into existence. ${ }^{17}$

Globalisation invites criticisms from many scholars, most of which is laid upon its paradox. Global modernity is then questionable because there is a belief that it produces inadequate developments, inequalities, too rapid urbanisation, leaves the peasantry in a precarious economic situation, and erodes and alienates people from their local cultures and religions. Some argued that solutions to modernity and globalisation are to be found in fundamentalist traditionalism that is in opposition with the global market systems and their laws. Some rely on nationalism as opposed to the egalitarian abstraction of global citizenship. Because of globalisation, they identify humanity with the market per se, the competitors, the consumers, etc. They also perceive human beings as bomo-economicus. The public sphere and discourse are systematically detheologised. Theology, God and holy houses are replaced with pseudo-

${ }^{17}$ Karen Armstrong, Islam: A Short History (Modern Library, 2002), p115; Amin Mudzakkir, Antara Iman dan Kewarganegaraan: Pergulatan Identitas Muslim Eropa, Jurnal Kajian Wilayah Eropa-UI, Vol. V., No. 1, 2009, pp. 46-61. 
religions in which transnational corporations serve as the high priests of the global temple.

Nevertheless, the project of globalism is now dealing with three challenges: (1) the emergence of a global Islamic political system; (2) the cultural reaction of Islamic fundamentalism against Westernisation, democracy and consumerism; and (3) the conflicting ideas between pluralism and fundamentalist commitments in respect to the different and sometimes conflicting values, lifestyle and beliefs. ${ }^{18}$ In Indonesia, the problems in respect with religiosity is, to mention some, whether Islam is to be integrated into the state of law or to be restricted to a personal life. As modernity came, religion began to be seen more as a matter of personal opinion rather than a subjective knowledge, and it, therefore, becomes problematic when some Muslim groups insist on the integration of Islamic laws and rules into modern bureaucracies. A debate on the Jakarta Charter in 1945, that is whether it is necessary to include Islamic law or not as the principle of Indonesian state, illustrates as a good example. ${ }^{19}$ Similarly, some Christians in Indonesia inclined also to reject modernity by referring to the historical past as the ideal future and insisted that science and knowledge will bring a more glorious future. In short, the believers are now struggling with the question of relationship between their religious traditions and modernity with all its developments and problems in science, technology, transportation, nuclear energy, chemical warfare, and other fields. The question includes how religions should face and respond to a modern and secular world in which global tensions are intensified also by a sense of suspicious feelings between Muslims and Christians, for example.

Hatred between Muslims and Christians took place since the colonial periods during which the former considered the latter as a part of colonisation. In Indonesia, we see that these global colonial encounters raised confrontation, admiration and imitation that influence Muslim communities. Meanwhile, Indonesian Muslims encounter also other alternative ideologies such as nationalism, capitalism and social communism, which are followed by the polarisation and the raise of

${ }^{18}$ Brian Turner, Orientalism, Modernism, and Globalization (New York: Routledge, 1994), p. 77.

${ }^{19}$ Jan S. Aritonang, Sejarah Perjumpaan Kristen dan Islam di Indonesia, Jakarta: BPK Gunung Mulia, 2004), p. 371. 
political streams among Indonesians in the twentieth century. Geertz, for instance, elucidates this polarisation among Javanese people into trichotomy, i.e. santri (pious Muslim), abangan (Javanese mystics) and priyayi (Javanese elites). ${ }^{20}$ Another example is that under the regime of President Soekarno, Indonesia was in resistance toward the domination of the West, while at the same time it systematically embraced capitalist and global economic systems during the New Order Regime led by President Suharto.

During the 1970s-1980s, global networks linked Islamic movements and Islamic fundamentalism in Indonesia to the spirit of Islamic resurgence. Islamic activists and the idea of revivalism were institutionalised in many contexts. During the New Order period, for example, we see the development of Islamic institutions, such as those exemplified by the growth of Islamic schools, clinics, hospitals, legal aids, disaster relief, youth centers, banks and Islamic political parties. Islam at the local level changes because of global influences from the emergence of Islamic revival movements in the late 1970's. The changing patterns of Muslim separatism in the Philippines, Thailand, Aceh, and the collapse of Communism as well as the issue of terrorism, have affects also on the Muslim communities at the local level.

\section{Religion \& Globalisation: Model of Responses}

It can be argued that religion would not be able to contribute positively to the social life unless its adherents transform and implement their religious values properly. It implies the necessity of reinterpreting religious themes when facing the current problems. Although religious symbols occupy a very high portion, yet the adherents' behaviors do not represent their religious values. The challenge is how, according to Evi, people should read their religious symbols in a more substantial, rather than merely a symbolic, manner. In line with this idea, Bagir, an Indonesian scholar, pointed out that the negative effects of globalisation may be resisted by making use of religious spirits in all fields. ${ }^{21}$ These were example of responses from some of participants during the "Bridge-

${ }^{20}$ Clifford Geertz, The Religion of Java, (New York: The Free Press, 1960).

${ }^{21}$ CRCS \& ICRS team, Workshop proceedings: Bridge-Building Dialogue. Unpublished, Yogyakarta, 2008, p. 5. 


\section{Building Program.”}

One response takes a clear-cut, ideological position against globalisation, referring to religion as an alternative and a cure. It argues that religion itself has a power to deal and overcome problems raised by globalisation. Nopri, a prominent leader of Hizbut Tahrir Indonesia/ HTI, for example, pointed out that Islam offers solutions to solve the problems of globalisation. This is so because, he said, Islam is not just a religion that only deals with worship toward the Creator, but it serves also as an ideology with detailed concepts of governing public affairs. Islam, he continued, provides a unique concept of economic, political, governmental, social, cultural, legal, educational systems. Therefore, Muslim, he insisted, should be more loudly and more optimistic about voicing the need to change the current world system. He also argues that Islam has no problem with globalisation as long as the term is understood as a process of human integration. Nopri suggested that Muslims must take advantage of technology, information, etc. HTI, he said, is a political party whose goal is to replace capitalism with Islamic civilisation. For him, globalisation is a comprehensive ideology of capitalism and covers all aspects of human life. Globalisation is a capitalist civilisation that attacks and hits all over the world, particularly the Muslim world. It attempts to erode Islamic identities and make Muslims identical with the West. The ultimate goal of globalisation, he said further, is human exploitation unhindered by the state, culture, rules, and of human values. ${ }^{22}$

Globalisation has an extraordinary negative impact on the world. HTI looks at the need for a better world, and it tries to disseminate that Islam, instead of capitalism, is a better alternative to the new world. ${ }^{23}$ Here, we can see that an Islamic organisation such as HTI takes a firm stand against globalisation in which it sees globalisation as a dangerous phenomenon that must be responded intelligently. Therefore, people must be fully aware in facing this phenomenon. Proactive attitudes must be developed in response to the universalisation of the capitalist ideology that is only exploiting the world, especially the Islamic one.

Some also argued that the impact of globalisation is ambivalent.

${ }^{22}$ Nopriadi, "Memahami Globalisasi: Proses Integrasi Umat Manusia dalam Arus Kapitalisme Global,” [http:/ / www.khilafah1924.org]. This paper is also presented at one of the three workshops, March 8-9, 2008.

${ }^{23}$ Nopriadi, "A Better World," pp. 7-8. 
Globalisation with its highly super-fast trend has negated humanitarian processes, leading to the alienated people. "The global trend established a tradition that is simple, fast and tends to see the core of the process at its physical and materialistic model, said Rahman, a Muslim participant. Other Muslim participant, for example, perceives that the positive impact of globalisation is very little, while the negative impact is more pertinent as the result of our own mistakes, especially those in the field of education. It is argued that "educational system in Indonesia is on the wrong track because it is only aimed at the developments of the brain and physics with a little attention on morality," said Thoha Abdurrahman. ${ }^{24}$ The reason why many people see globalisation in a negative way is due to its ignorance on human morality and spirituality.

The above ambivalent responses to globalisation strengthen Berger's pessimistic opinion on Islam in dealing with globalisation. Islam has unfavorable aspects to the development of a global civil society, i.e. its understanding and interpreting of law, jihäd and the role of women that have been traditionally defined as having inferior status. The notion of shari'ah, for example, is inherent in the relation between religion and state, which hinders the modern economic development and the global civil society institutions. ${ }^{25}$ The obstruction of economical and politic developments under globalisation is due to religious polarisation as well. Interpretation on histories, texts and political interests stimulate hostility and separation within one religion. It takes place globally, either among Catholics in Northern Ireland, Buddhism in Sri Lanka, or Islam in Southeast.

Some participants attempt to integrate between locality, nationality and globality. It does not mean that this group fully accepts globalisation without any notice; rather, they combine it with their local culture in a critical manner. In an integrative way, religious communities may "accept" globalisation as part of the process of their lives as outlined by God, in which human beings, as a caliphate in the world is assigned to "escort" globalisation. Those who belong to this idea argued that all of humankind has in fact common good interests. Human beings can learn from each

${ }^{24}$ Workshop proceedings, p. 10.

${ }^{25}$ Peter L. Berger, "Religion in Global Civil Society" in Mark Juergensmeyer (ed.), Religion in Global Civil Society (Oxford University Press, 2005), p. 18. 
other so that they can work together and eventually live side by side as one single family. The integrative sides of globalisation in Indonesia take the form of socio-political changes that include openness. Indonesian people are more concerned with at least four global issues, including democracy, human rights and environmental sustainability as well as the freedom of the press as an integral part of social communication systems.

There are also participants who hold an exclusive response in which they reject globalisation as it threatens morality, spirituality and religion. Globalisation does not only create an increasingly consumerist, apathetic, individualistic society but also it erodes and alienates people from their local cultures and religions. They refuse globalisation by excluding themselves from this global phenomena or even strengthening their own identities. In fact, this tendency is found in all religious communities, including Islam, Christianity, Hinduism and other fundamentalists in several places. It is become undeniable fact. In this sense, globalisation appeared as a paradox in which it triggers uniformity and homogeneity in terms of communication systems and lifestyles and at the same time, it strengthens cultural heterogeneity in the form of primordialism, cultural localism and religious fundamentalism. This negative response follows from the belief that religion is only about spiritual, nothing to do with social responsibility. It neglects the fact that religion can give a positive response when its believers are willing to cooperate, develop ethics in order to provide a positive contribution to this nation, as to work together to tackle the problems of poverty. They blame that globalisation along with its tools such as the internet, pluralism projects, secularism and liberalism is a conspiracy theory of Judaism to destroy Islamic world. Jewish people become a scapegoat since they proved to be able to produce "superhuman," scientists, capitalists; those people become puppet masters (dalang), who are working with America and Israel to control the world. ${ }^{26}$

${ }^{26}$ For example, Dewan Dakwah under the leadership of Muhammad Natsir is in polemic against Christianity and Judaism, and it believes that globalisation put Islam under the new threats of a new Christian Crusade and international Jewish conspiracies. This hatred pursued Committee for Solidarity with the World of Islam (KISDI) during the 1990s, which then actively pressured the government to protect Muslims in Indonesia from any Western influence; see Martin van Bruinessen, "Global and local in Indonesian Islam,” Southeast Asian Studies, vol. 37, no.2 (1999), pp. 46-63. 


\section{E. Conclusion}

Looking at different responses above, we may also conclude that there are opportunities and constraints for an interfaith cooperation to take place in response on globalisation. Seen as an integration of time and space, globalisation is an avoidable phenomenon to which all religions should deal with. In the context of pluralistic Indonesian societies, the bad impacts of globalisation in the form of, to mention some, poverty, morality, and ecological problems, are issues to which all religions in the country have to face. In this sense, interfaith cooperation become more feasible when all different religions regard those real problems as their common concerns, regardless of their theological differences. Therefore, it seems that an integrative response as explained earlier is the best for the realisation of interfaith cooperation since it implies that globalisation generates a common concern on the destructive impacts of globalisation on religions.

Religion is required to collect, move, and empower all moving in unison to realise the ecological measures as a form of faith. Religion makes his followers for daring to talk about ecological issues, so that humans and all creatures are protected from natural disasters, religion can also urged his followers to seek an agreement to end the destruction of God's creation. Religions are supposed to encourage their followers to conduct interfaith cooperation in order to find alternatives that can bring life to each other and make this world better. Religion should become a community of hope for those who need assistance from the threat of the hope of life in the middle of the absence of climate change in the current fierce. 


\section{BIBLIOGRAPHY}

Aritonang, Jan, S, Sejarah Perjumpaan Kristen dan Islam di Indonesia, Jakarta: BPK Gunung Mulia, 2004.

Azra, Azyumardi, The Origins of Islamic Reformism in Southeast Asia: Networks of Malay-Indonesian and Middle Eastern "Ulama" in the Seventeenth and Eigteenth Centuries, University of Hawai'i, 2004.

Berger, Peter L, "Religion in Global Civil Society" in Mark Juergensmeyer (ed.), Religion in Global Civil Society, Oxford University Press, 2005.

Beyer, Peter. Systemic Religion in Global Society. Inside The Transnational Studies Reader: Intersections and Innovations. Sanjev Khagram and Peggy Levitt (eds.), New York and London: Routledge, 2008.

Bruinessen, Martin van, "Global and local in Indonesian Islam," Southeast Asian Studies (Kyoto) vol. 37, no.2, 1999.

Clifford Geertz, The religion of Java. New York: The Free Press, 1960.

CRCS-ICRS, Workshop Proceedings, Bridge Building Dialogue, Globalization: Challenge \& Opportunities for Religion, Yogyakarta, 2008.

Esposito, John L; Fasching Darrell; Lewis Todd., Religion and Globalization. World Religions in Historical Perspective, Oxford: Oxford University Press, 2008.

Huntington, Samuel, The Clash of Civilizations and the Remaking of World Order. New York: Simon and Schuster, 1996.

Knitter, Paul, "Globalization and the Religions: Friends or Foes?" unpublished paper presented on May 24, 2006 at a Research Seminar on Globalization and Religion: Friends or Foes? at Centre for Religious and Cross-Cultural Studies, Gadjah Mada University, Yogyakarta.

Loy, David R, 'The Religion of the Market' in Journal of the American Academy of Religion, vol. 65, no. 2, Summer 1997.

Mudzakkir, Amin, "Antara Iman dan Kewarganegaraan: Pergulatan Identitas Muslim Eropa," Jurnal Kajian Wilayah Eropa-UI, Vol. V., No. 1, 2009.

Nopriadi, "Globalization, Media and education of young people". A paper presented at the workshop, 8-9 March 2008 by the Center for 
Hatib A. Kadir \& Maufur

Religious and Cross - Cultural Studies (CRCS) and the Indonesian Consortium for Religious Studies (ICRS-Yogya).

----, "Memahami Globalisasi: Proses Integrasi Umat Manusia dalam Arus Kapitalisme Global," [http://www.khilafah1924.org] . This paper is also presented at one of the three workshops, March 8-9, 2008.

Ray, Larry, Globalization: Everyday Life, New York: Routledge, 2007.

Ricklef, Merle. Polarizing Javanese Society, Islamic and Other Visions (c 18301930), Honolulu: University of Hawaii Press, 2007.

Robertson, Roland, Globalization: Social Theory and Global Culture, London: Sage, 1992.

Steger, Manfred B, Globalization: A Very Short Introduction, Oxford: Oxford University Press, 2009. 